\title{
Retracted: A Survey of Home Delivery and Newborn Care Practices among Women in a Suburban Area of Western Nigeria
}

\author{
International Scholarly Research Notices \\ Received 5 July 2015; Accepted 5 July 2015 \\ Copyright (C 2015 International Scholarly Research Notices. This is an open access article distributed under the Creative Commons \\ Attribution License, which permits unrestricted use, distribution, and reproduction in any medium, provided the original work is \\ properly cited.
}

The paper titled "A Survey of Home Delivery and Newborn Care Practices among Women in a Suburban Area of Western Nigeria" [1] has been retracted as it is found to contain a substantial amount of material from the published paper in BMC Pregnancy and Childbirth 2006 titled "Home delivery and newborn care practices among urban women in western Nepal: a questionnaire survey" by Chandrashekhar T. Sreeramareddy, Hari S. Joshi, Binu V. Sreekumaran, Sabitri Giri, and Neena Chuni.

\section{References}

[1] L. M. Adelaja, "A survey of home delivery and newborn care practices among women in a Suburban area of Western Nigeria," ISRN Obstetrics and Gynecology, vol. 2011, Article ID 983542, 9 pages, 2011. 